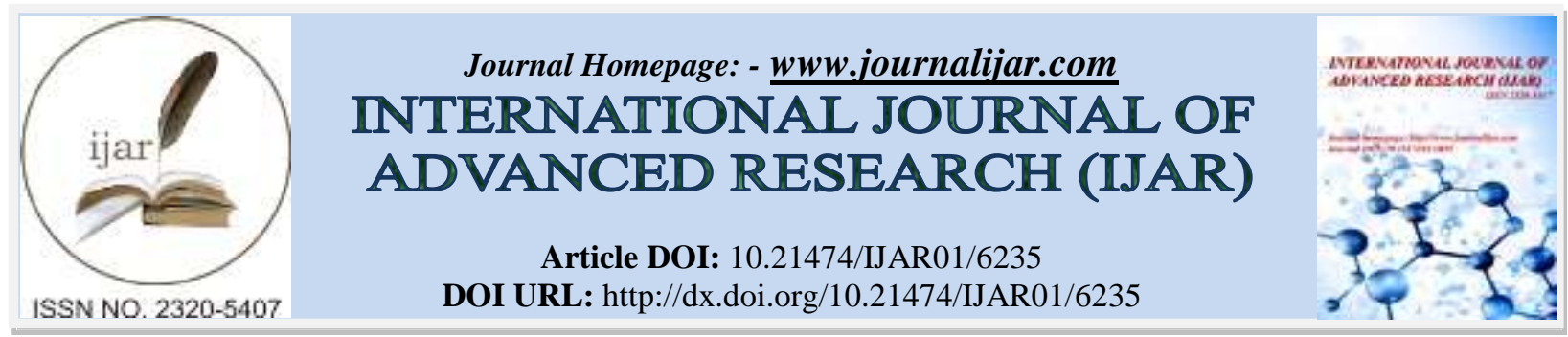

RESEARCH ARTICLE

\title{
IDENTIFICATION OF CANCER STEM CELLS IN ORAL SQUAMOUS CELL CARCINOMA USING CRIPTO-1.
}

Yasmine Alaa El-Din ${ }^{1}$, Amina Fouad Farag ${ }^{1}$ and Nadia Fathy Hassabou ${ }^{2}$.

1. Assistant Lecturer, Oral Pathology Department, Faculty of Dentistry, October 6 University, Egypt.

2. Lecturer, Oral Pathology Department, Faculty of Dentistry, October 6 University, Egypt.

\section{Manuscript Info}

Manuscript History

Received: 06 November 2017

Final Accepted: 08 December 2017

Published: January 2018

Key words:-

Cancer Stem Cell (CSC),

Cripto-1 (CR-1),

OSCC, Immunofluorescent

\section{Abstract}

Background: Oral squamous cell carcinoma (OSCC) is still one of the most common lethal malignancies of the oral cavity. One of the reasons for its treatment failure is thought to be related to the presence of a subpopulation of cells within the tumor called cancer stem cells (CSCs). CSCs display stem cell-like characteristics that impart resistance to conventional treatment modalities and promote tumor initiation, progression, and metastasis. Specific markers for this population have been investigated in the hope of developing a deeper understanding of their role in the pathogenesis of OSCC and elucidating novel therapeutic strategies. Over the past years, different techniques and markers have been investigated. Cripto-1(CR-1) is an identified oncogene which was overexpressed in a wide spectrum of human malignant solid tumours, introducing a potential therapeutic target for human cancers and was significantly associated with initiation and aggressiveness of human cancers.

Methods: In this study 40 samples of well and poorly differentiated squamous cell carcinoma were obtained to study the difference of cripto-1 expression according to the degree of differentiation using the immunofluorescent technique.

Results: CR-1 was over expressed in well differentiated samples compared to poorly differentiated samples and immunofluorescent expression showed significant decrease in mean percentage $(\mathrm{P}<0.05)$.

Conclusion: CSCs has a role in initiation and progression of OSCC and CR-1 can be considered as a good marker for detection of these cells.

Copy Right, IJAR, 2018,. All rights reserved.

\section{Introduction:-}

Oral squamous cell carcinoma (OSCC) is an aggressive epithelial malignancy that accounts for approximately 3-4\% of malignancies diagnosed annually worldwide and about $97 \%$ of malignant tumors of the oral cavity (Choi \& Myers, 2008 and Mariotto et al., 2011).

OSCC is considered a threat to public health due to the capabilities of its cells for local invasion into surrounding tissue, metastasis to distant sites and recurrance which in turn responsible for its poor clinical outcome and high morbidity rate (Jemal et al., 2006 and Zini et al., 2010). 
Such capabilities can be attributed to the presence of a small undifferentiated subpopulation of cells with stem-like, self-renewing properties capable of differentiating within the tumor termed cancer stem cells (CSCs) (Ye et al., 2015).

CSCs are highly tumorigenic with a greater capacity for migration, invasion, and proliferation compared to the other cancer cells (Chen, 2009 and Okamoto et al., 2009) and are believed to be largely responsible for the biological characteristics of cancer namely, rapid growth, invasion, metastasis (Yanamoto et al., 2011) and even recurrence after conventional therapy due to their increased resistance against radio and chemo-therapeutic modalities (Oshimori et al., 2015).

Over the past years, a substantial number of studies on many solid tumors including glioblastoma (Tysnes et al., 2013), breast cancer (Al-Hajj et al., 2003), prostate cancer (Collins et al, 2005), pancreatic cancer (Hermann et al., 2007), colorectal cancer (Dalerba et al.,2007) and OSCC (Zhang et al., 2010) support the role of CSCs where their targeted elimination can present a new conceptual framework for oral cancer risk assessment, early detection, prognosis, prevention and treatment and becomes increasingly crucial for clinical and basic tumor research (Tirino et al., 2008, Prince et al., 2007 and Satpute et al., 2013).

However, most of these stem cell markers including CD133, CD44,...etc. used in the above studies were empirical and derived from normal stem cells which are known to be largely tissue specific which inturn had raised an important question regarding the specificity and reliability of such CSC markers (Baillie et al., 2017 and Liu et al., 2017).

This finding is further complicated by the presence of multiple CSC subtypes within the same tumor and among different tumors, making the investigation more reliant on the use of multiple markers and rise the urge to identify a CSC marker specific for the OSCC in order to improve the diagnostic capabilities and treatment efficacy (Baillie et al., 2017).

Cripto-1 (CR-1), also referred to as teratocarcinoma-derived growth factor-1 (TDGF-1), has showed a promising potential as a functional marker for the identification and isolation of CSC from OSCC based on the finding that the CR-1 high OSCC cells express high level of stemness-related genes and possess high potential of self-renewal and high ability of tumorigenesis (Normanno et al., 2004 and Yoon et al., 2011).

CR-1 is a member of the epidermal growth factor- Cripto/FRL1/Cryptic as a cysteine- rich region (EGF-CFC) gene family that is involved in embryonic development, embryonic stem cell self-renewal, pluripotency capabilities g tumor progression and maintenance. Remarkably, it is expressed in CSCs compartments, modulating and boosting cancer cell proliferation, migration, invasion, epithelial mesenchymal transition (EMT) and angiogenesis (Klauzinska et al., 2014).

It also participates in multiple cell signaling pathways including Wnt, Notch, and TGF- $\beta$ which are directly involved in embryogenesis, cell differentiation, proliferation, migration, organogenesis, epithelial-to-mesenchymal transition (EMT) and apoptosis (Bianco et al., 2010 and Klauzinska et al., 2014) and their deregulation plays a fundamental role in tumorigenesis (Wu et al., 2017).

Overexpression of CR-1 is found to be correlated between CR-1 with high grade, moderately- and welldifferentiated breast and cervical carcinomas, gastric adenocarcinomas, OSCC and bladder cancer (Wei et al., 2015, Zhang et al., 2010, Yoon et al., 2011, Gong et al., 2007), although no correlation was reported between CR-1 expression and the tumor grade in pancreatic neoplasms (Wu et al. 2009). Such results had presented it as an effective marker to predict cancer initiation and progression and even as a potential therapeutic target for a number of human cancers.

Although the important role of this CSCs marker in different cell signaling pathways and its possible association with tumorgenesis in various human malignancies, Only few studies has investigated its role in OSCC (Yoon et al., 2011).

Therefore, this study aimed to estimate the potentiality of CR-1 as a specific CSC marker for OSCC and to investigate its expression among the different grades of OSCC and its association with tumor progression. 


\section{Material and Methods:-}

Tissue Specimens and Histopathological Study:-

Forty specimens were collected as 20 specimens of well differentiated and another 20 poorly differentiated OSCC obtained from the archives of the Oral and Maxillofacial Pathology Department, Faculty of Dentistry, Cairo University and the Department of Surgical Pathology, National Cancer Institute, Cairo University were used in the present study. In addition to 6 specimens of normal appearing oral mucosa were taken from free tumor margins to be employed as control group

Two serial $4 \mu \mathrm{m}$ thick sections were cut from each formalin-fixed, paraffin-embedded tissue block, one section was mounted on ordinary glass slide, for routine stain with H\&E to be examined under ordinary light microscope in order to confirm previously made diagnosis of the selected specimens. The other section was mounted on positively charged slides for immunostained with anti-CR-1 antibody.

\section{Immunofluorescence Study:-}

The cells were $4 \%$ formaldehyde fixed $(10 \mathrm{~min})$ and then incubated in 1\% BSA / 10\% normal goat serum / $0.3 \mathrm{M}$ glycine in $0.1 \%$ PBS-Tween for $1 \mathrm{~h}$ to permeabilise the cells and block nonspecific protein-protein interactions. The cells were then incubated with the primary anti-Cripto1 antibody, rabbit polyclonal antibody of IgG type (ab19917, $5 \mu \mathrm{g} / \mathrm{ml}$ ) overnight at $+4^{\circ} \mathrm{C}$. The secondary antibody (green) was Alexa Fluor ${ }^{\circledR} 488$ goat anti-rabbit $\operatorname{IgG}(\mathrm{H}+\mathrm{L})$ used at a 1/1000 dilution for $1 \mathrm{~h}$. Alexa Fluor ${ }^{\circledR} 594$ WGA was used to label plasma membranes (red) at a 1/200 dilution for $1 \mathrm{~h}$. DAPI was used to stain the cell nuclei (blue) at a concentration of $1.43 \mu \mathrm{M}$. All markers were supplied by Abcam, UK.

\section{Identification and Counting of CR-1 Positive Cells:-}

Fluorescent images were visualized using a fluorescence microscope equipped with digital camera.

Manual counting was used to determine the number of CR-1 cells and the data were expressed as number of counted CR-1+ cells where: + is few (CR-1+ cell count is <1000), ++ is medium (CR-1+ cell count is between 1000-5000) and +++ is many (CR-1+ cell count is $>5000)$, while mean percentage represents the mean total counts / slides number in each group(31).

\section{Statistical Analysis:-}

Data were statistically analyzed using Statistical Package for Social Scientists (SPSS) 10.00 for windows. All values were expressed at mean percentages and standard deviation (mean \pm S.D).

At confidence interval of $95 \%, \mathrm{p}$-value was considered significant when it is below 0.05 level.

\section{Results:-}

\section{Histopathological Findings:-}

Forty specimens of OSCC, were classified into 20 cases of well differentiated OSCC that characterized by presence of keratin pearls and cell nests, nuclear hyperchromatism, few cellular and nuclear pleomorphism (fig. 1). While the other 20 cases were poorly differentiated OSCC that show neither keratin pearls nor cell nests while the malignant cells invaded the underlying connective tissue in the form of diffuse sheets with extreme pleomorphism, hyperchromatism and aberrant mitotic figures (fig.2). 


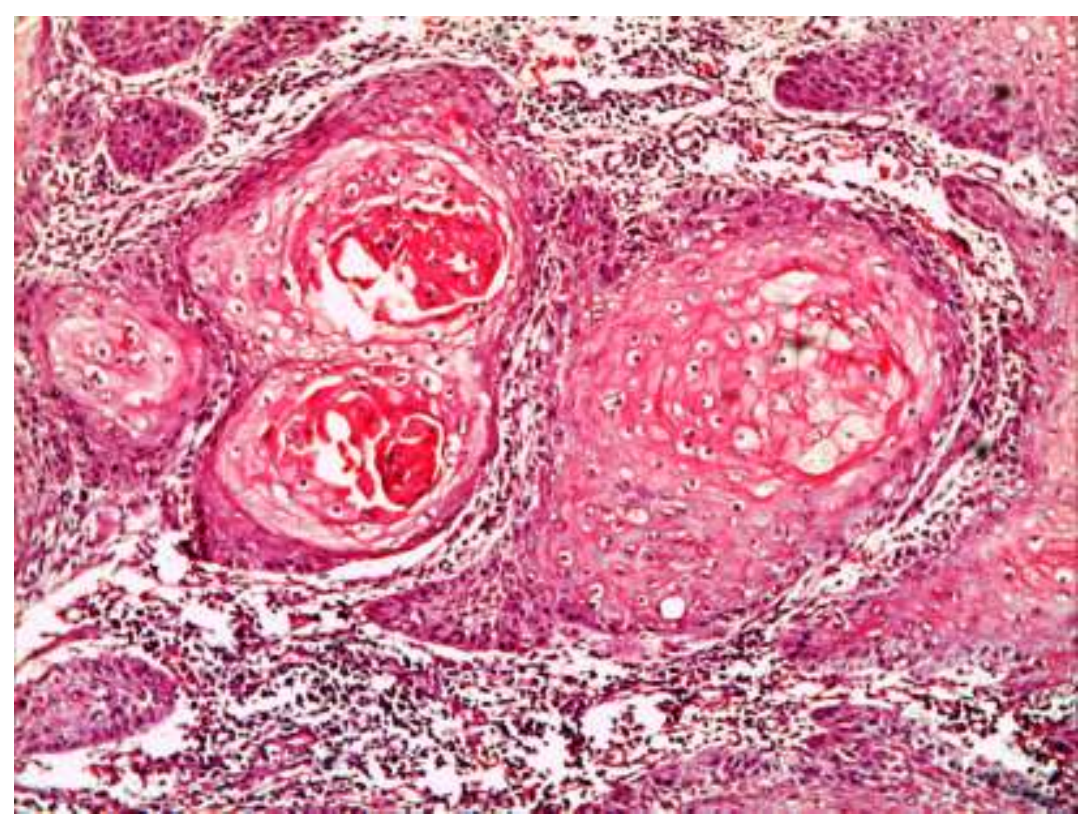

Figure 1:- Well differentiated OSCC showing keratin pearls and cell nests (x100).

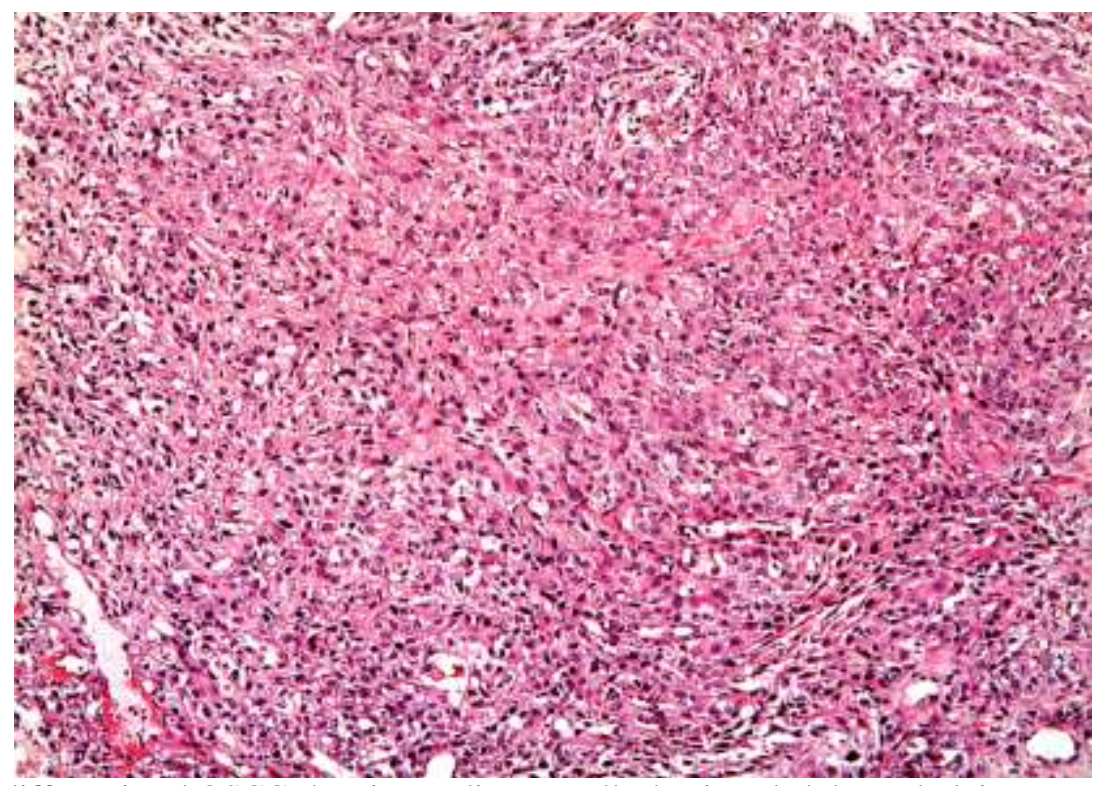

Figure 2:- Poorly differentiated OSCC showing malignant cells that invaded the underlying connective tissue in the form of diffuse sheets (x100).

\section{Immuno-Fluorescent Findings:-}

Eight cases of well differentiated OSCC showed medium count of CR-1 positive cells (++) while the remaining cases revealed many CR-1 positive cells (+++) that arranged in clusters, (fig. 3), table (1). The mean percentage of scoring was $84.34 \%$.

While in poorly differentiated OSCC, sixteen cases revealed few sporadic CR-1 positive cells $(+)$ while the remaining cases demonstrated medium count of CR-1 positive cells figure (++) (4), table (1). The mean percentage of scoring was $42.55 \%$. 


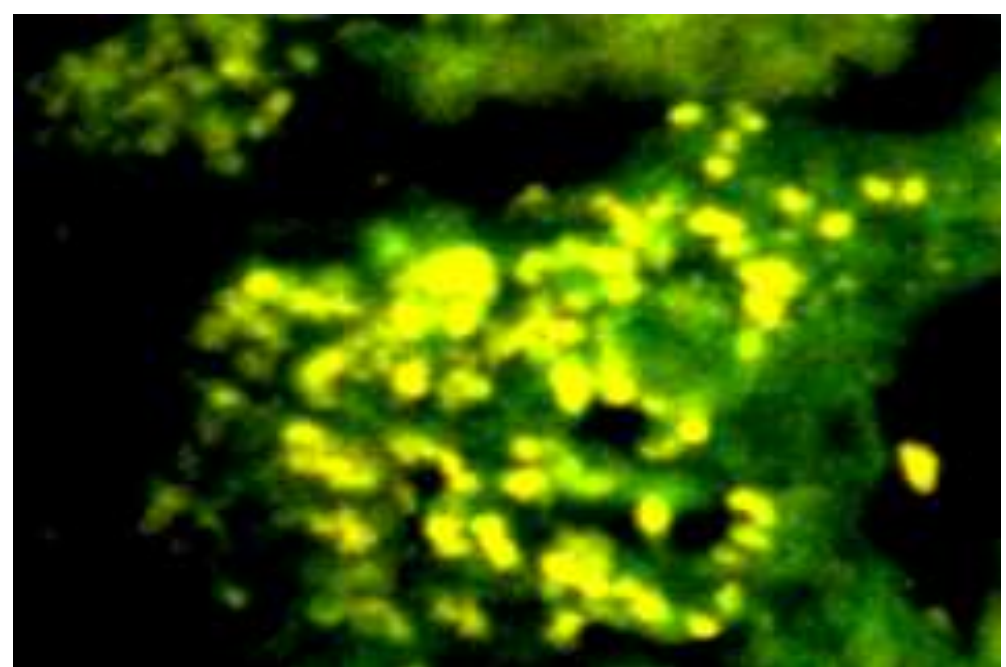

Figure 3:- Immunofluorescence of well differentiated OSCC showing many clusters of CR-1 positive cells.

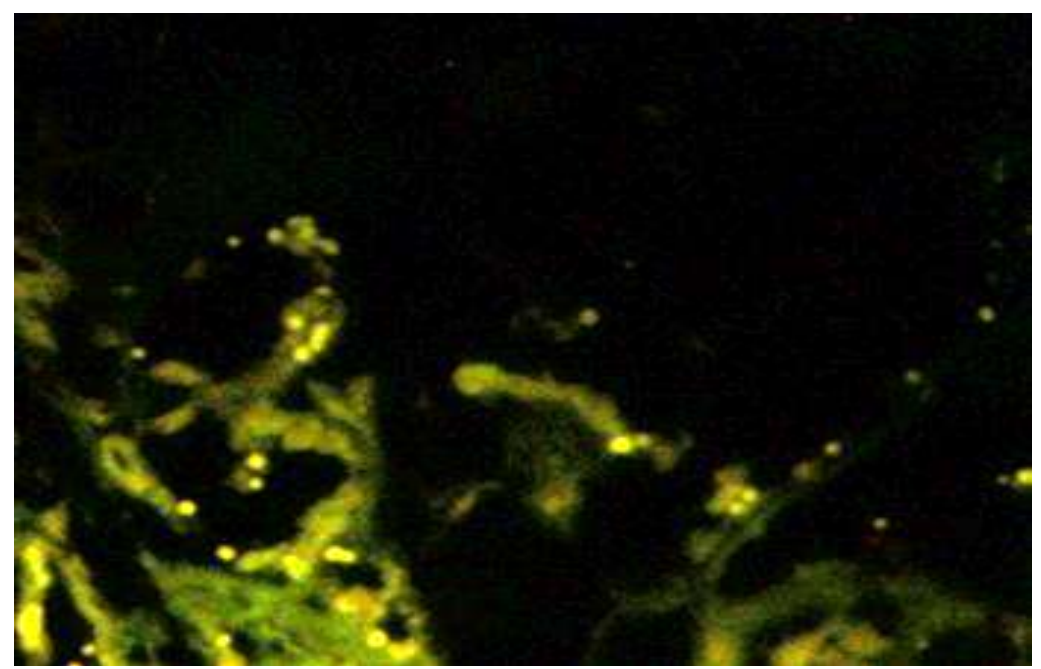

Figure 4:- Immunofluorescence of poorly differentiated OSCC showing few sporadic CR-1 positive cells.

Table 1:- Individual scoring of CR-1 +ve cells in different grades of OSCC.

\begin{tabular}{|c|c|c|c|c|c|c|c|c|c|}
\hline Diagnosis & \multicolumn{2}{|c|}{$\begin{array}{l}\text { Samples/ } \\
\text { Scoring }\end{array}$} & \multicolumn{2}{|c|}{$\begin{array}{c}\text { Samples/ } \\
\text { Scoring }\end{array}$} & Diagnosis & \multicolumn{2}{|c|}{$\begin{array}{c}\text { Samples/ } \\
\text { Scoring }\end{array}$} & \multicolumn{2}{|c|}{$\begin{array}{l}\text { Samples/ } \\
\text { Scoring }\end{array}$} \\
\hline \multirow{11}{*}{$\begin{array}{c}\text { Well } \\
\text { differentiated } \\
\text { OSCC }\end{array}$} & 1 & +++ & 11 & ++ & \multirow{11}{*}{$\begin{array}{c}\text { Poorly } \\
\text { differentiated } \\
\text { OSCC }\end{array}$} & 1 & + & 11 & + \\
\hline & 2 & +++ & 12 & ++ & & 2 & + & 12 & + \\
\hline & 3 & ++ & 13 & +++ & & 3 & + & 13 & + \\
\hline & 4 & +++ & 14 & ++ & & 4 & ++ & 14 & + \\
\hline & 5 & ++ & 15 & +++ & & 5 & + & 15 & + \\
\hline & 6 & +++ & 16 & ++ & & 6 & + & 16 & ++ \\
\hline & 7 & +++ & 17 & +++ & & 7 & + & 17 & + \\
\hline & 8 & +++ & 18 & +++ & & 8 & ++ & 18 & + \\
\hline & 9 & +++ & 19 & ++ & & 9 & ++ & 19 & + \\
\hline & 10 & +++ & 20 & ++ & & 10 & + & 20 & + \\
\hline & \multicolumn{4}{|c|}{ Mean percentage $84.34 \%$} & & \multicolumn{4}{|c|}{ Mean percentage $42.55 \%$} \\
\hline
\end{tabular}




\section{Statistical Findings:-}

When the well differentiated OSCC compared to poorly differentiated ones, immunofluorescent expression showed significant decrease in mean percentage of CR-1 positive cells $(\mathrm{p}<0.05)$, (graph 1$)$.

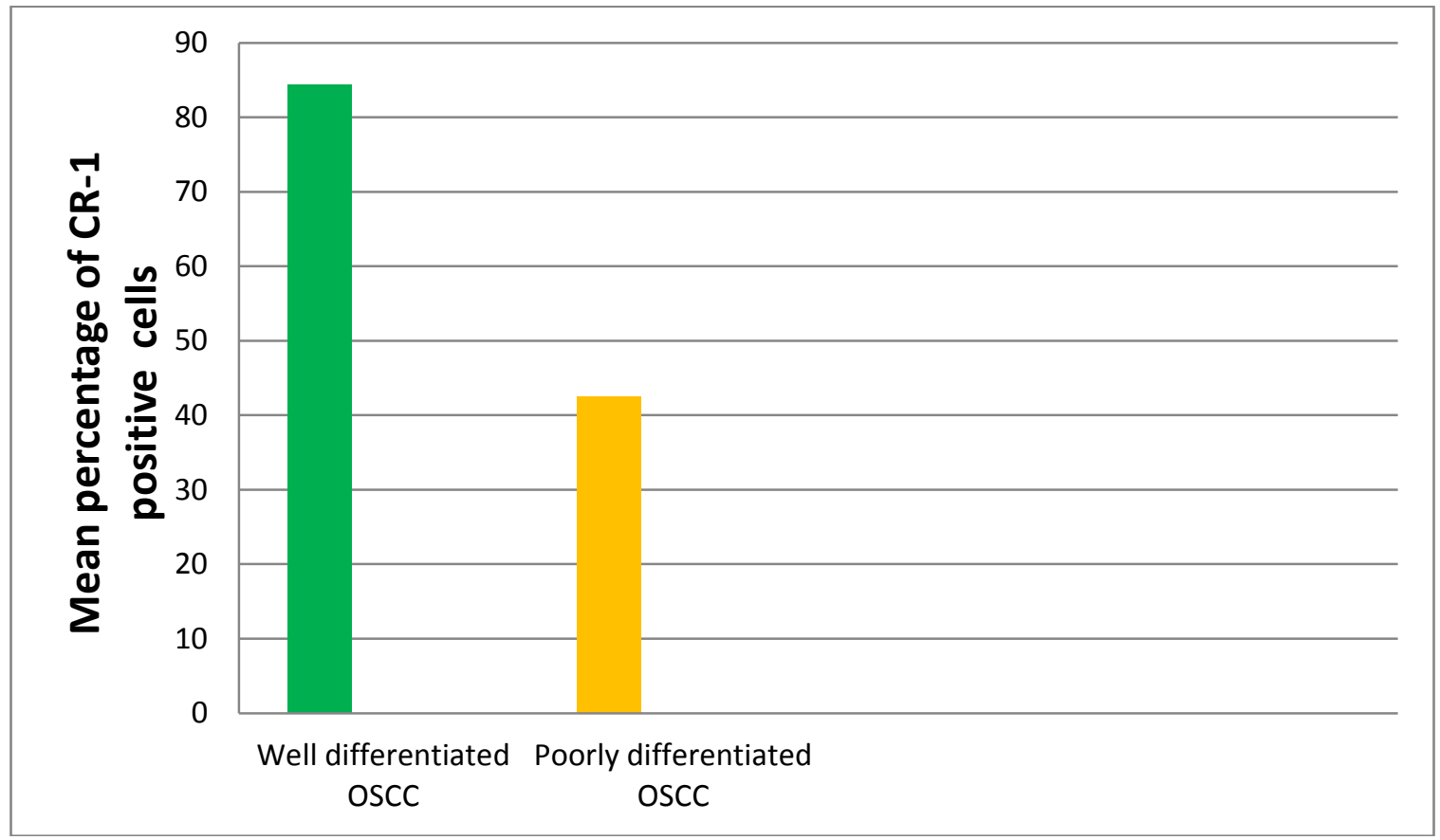

\section{Discussion:-}

OSCC is still considered the most common malignancy of the oral cavity and the most lethal cancer due to the late detection of this cancer in its advanced stages despite the easy accessibility of the oral cavity for regular examinations (Perez et al., 2013). Several markers were discovered to correlate the relation between this cancer and CSCs and the role of these cells in tumor aggressiveness, such as CD44 and CD109 (Hema et al., 2014).

CSCs have shared a new era in the field of pathogenesis of OSCC in oral cavity. They are the most promising technology to conduit between the bench and beside. This importance comes from their ability for perpetual selfrenewal and proliferation, producing downstream progenitor cells and cancer cells that drive tumor growth. Studies on many cancer types including OSCC identified CSCs using specific markers, but it is still unclear as to where in the stem cell hierarchy these markers fall (Baillie et al., 2017).

Considering the promising results of CR-1 as a member of the EGF-CFC protein family and its involvement in the activation of several different signaling pathways during embryonic development, we have chosen it in this work. Although the CR-1 protein was over expressed in several human cancers including breast, colon, cervix, gastric, and pancreatic cancer (Bianco et al., 2010 and Francescangeli et al., 2015), no one shed the light on its importance as a novel marker for CSC and to the best of our knowledge, only one study evaluated CR-1 expression in OSCC (Yoon et al., 2011). Therefore, the current work investigated the CR-1 expression in clinical samples of OSCC using immunoflurescence, to analyze the correlation between CR-1 expression as a CSC marker and the different grades in OSCC.

In the current work, the immunoflurescent results showed high expression in well differentiated samples comparing to low expression in poorly differentiated ones. These results were supported by the immunohistochemical findings by (Yoon et al., 2011). Also, was in the same line of our previous study (Hassabou et al, 2011) in which we used CD44v6 as a CSC marker and also, was in agreement with (Lee et al., 2008 \& Klonisch et al., 2008 \&Yanamoto et al., 2011). There was a significant correlation between CR-1 expression and the histological differentiation of OSCC and this was explained by that CR-1 plays an important role in the malignant transformation of the oral mucosa and it is involved in the tumorigenesis and progression of OSCC by promoting the growth and migration of malignant cells. 
Lee et al. (2008) studied the expression of CD44 in OSCC, the demonstrated irregular staining of CD44 in tumor cells which shown to be associated with poor tumor differentiation and advanced stage. Conversely, another study by $\mathrm{Yu}$ et al. (2015) found no prognostic significance of CD44v6 expression in OSCC. The significant decrease in CSCs count with increasing the grade of OSCC detected in the current work could be explained on the basis of the earlier observations which implicated CSCs in initiation of different solid tumors including HNSCC (Burkert et al., 2006). Moreover Choi et al. (2008) and Tsai et al. (2014) were in accordance with our results using Oct-4 as CSC marker. They clarified that Oct-4 plays a role in tumor transformation, tumorigenicity, invasion and metastasis within OSCC and proposed that Oct-4 promotes tumor initiation by playing a role in the regulation of EMT.

In agreement with our results were the PCR results of Mahmoudian et al. (2017). There was a significant correlation observed between CR-1 expression and tumor differentiation grade and progression stage of the studied cases of esophageal squamous cell carcinoma (ESCC). This was clarified that over expression of CR-1 is involved in the development of ESCC. A small subpopulation of either adult or progenitor stem cells can contribute to CSCs, which support the growth and maintenance of tumor cells in most types of cancers including colon, breast, prostate and ESCC (Forghanifard et al., 2014). Therefore, investigation of stem cell regulatory genes in cancers may help to identify potential biological markers for early diagnosis. Therefore, this indicated that CR-1 might represent an example of an embryonic gene that is re-expressed, possibly in stem cells in adult tissues, in an inappropriate fashion and thereby may contribute to the pathogenesis of cancer. Furthermore, over expression of CR-1 in human tumors may confirm the linkage between stem cell biology and tumor development (Schier et al., 2003) and increase the demand of identifying effective markers to predict cancer initiation and progression (Wei et al., 2015).

CR-1 has a key regulatory role in early embryogenesis, oncogenic proliferation, and transformation via its activity in multiple signal transduction pathways, which include TGF- $\beta$, Notch, and Wnt signaling cascades. CR-1 over expression can induce cell proliferation, EMT and tumour angiogenesis (Strizzi et al., 2004). CR-1 induces invasion, tumor cell proliferation, cellular migration, and cell motility in many different cancers (Yoon et al., 2011). The expression profiles of a number of protein markers have been studied as putative CSC markers within OSCC samples and cell lines. Finally, no single marker has been shown to unequivocally identify CSCs and it is likely that CSCs exist in an overlapping hierarchy of cell population subsets. Consequently, the majority of CSC characterization research relies on using combinations of these markers (Liu et al., 2017).

\section{Conclusion:-}

From the current study it can be concluded that there is a small population of cells with stem cell properties referred to CSCs which play an important role in tumor initiation.

\section{Conflict of interest:-}

All authors declare that no conflict of interest.

\section{References:-}

1. Al-Hajj, M., Wicha, M., Benito-Hernandez, A., Morrison, S. and Clarke, M. (2003): Prospective identification of tumorigenic breast cancer cells. Proc. Natl. Acad. Sci. U S A,100:3983-3988.

2. Baillie, R; Tan, S, Tand Itinteang,T (2017): Cancer Stem Cells in Oral Cavity Squamous Cell Carcinoma: A Review. Frontiers in Oncology, V (7), 112:1-10.

3. Bianco, C; Rangel, MC; Castro, NP; Nagaoka,T; Rollman, K and Gonzales, M and Salomon, D (2010): Role of Cripto-1 in Stem Cell Maintenance and Malignant Progression. The American Journal of Pathology, Vol. 177, No. 2, 1-9.

4. Burkert, J; Wright, N.A; Alison, M.R (2006): Stem cells and cancer: an intimat relationship. J Pathol.; 209: 287-297.

5. Chen, Z. (2009): The cancer stem cell concept in progression of head and neck cancer. J. Oncol., 2009:894064.

6. Chiou, SH; Yu, CC; Huang, CY; Lin, SC; Liu, CJ; Tsai, TH et al (2008): Positive cor-relations of Oct-4 and Nanog in oral cancer stem-like cells and high-grade oral squamous cell carcinoma. Clin Cancer Res., 14(13):4085-95.

7. Choi, S. and Myers, J. (2008): Molecular pathogenesis of oral squmous cell carcinoma: Implications for therapy. J. Dent. Res., 87(1):14-32.

8. Collins, A., Berry, P., Hyde, C., Stower, M. and Maitland, N. (2005): Prospective identification of tumorigenic prostate cancer stem cells. Cancer Res., 65:10946-10951. 
9. Dalerba, P., Dylla, S., Park, I., Liu, R., Wang, X., Cho, R., et al. (2007): Phenotypic characterization of human colorectal cancer stem cells. Proc. Natl. Acad. Sci. U S A, 104:10158-10163.

10. Forghanifard MM, Khales SA, Javdani-Mallak A, Rad A, Farshchian M, Abbaszadegan MR (2014): Stemness state regulators SALL4 and SOX2 are involved in progression and invasiveness of esophageal squamous cell carcinoma. Medical Oncology ; 31(4):1-8.

11. Forghanifard, MM; Taleb, S; Abbaszadegan, MR (2015): Notch Signaling Target Genes are Directly Correlated to Esophageal Squamous Cell Carcinoma Tumorigenesis. Pathology \& Oncology Research; 21(2):463-7.

12. Gong, Y., Yarrow, P., Carmalt, H., Kwun, S., Kennedy, C., Lin, B. et al. (2007): Overexpression of Cripto and its prognostic significance in breast cancer: A study with long-term survival. EJSO, 33(4):438-443.

13. Hassabou, N; Kasem, R and Farag, H (2011): Precancerous and Cancerous Stem Cells in Oral Ep ithelial Dysplasia and Oral Squamous Cell Carcinoma (An Immunofluorescent Study). E.D.J. Vol. 57, No. 3

14. Hema,KN; Rao, K; Devi, U; Priya, NS; Smitha, T and Sheethal, HS (2014): Immunohistochemical study of CD44s expression in oral squamous cell carcinoma-its correlation with prognostic parameters. J Oral Maxillofac Pathol. May-Aug; 18(2): 162-168

15. Hermann, P., Huber, S., Herrler, T., Aicher, A., Ellwart, J., Guba, M., et al., (2007): Distinct populations of cancer stem cells determine tumor growth and metastatic activity in human pancreatic cancer. Cell Stem Cell, 1:313-323.

16. Jemal, A., Sieger, R., Ward, E., Murray, T., Xu, J., Smigal, C. and Thun, M. (2006): Cancer statistics, 2006. CA. Cancer J. Clin., 56(2):106-130.

17. Klauzinska, M., Castro, N., Rangel, M., Spike, B., Gray, P., Bertolette, D. et al. (2014): The multifaceted role of the embryonic gene Cripto-1 in cancer, stem cells and epithelial-mesenchymal transition. Semin. Cancer Biol., 29:51-58.

18. Klonisch, T; Wiechec, E; Hombach-Klonisch S., Ande S., Wesselborg S., Schulze-Osthoff K., Los M (2008): Cancer stem cell markers in common cancers - therapeutic implications.Trends Mol. Med.; 14:450-460.

19. Lee, C.Jl Dosch J., Simeone D.M (2008): Pancreatic cancer stem cells. Journal of Clinical Oncology; 26: 28062812.

20. Liu, Q; Cui, X; Yu, Xi; Bian, B.S.J; Qian, F; Hu, Xu.G; Ji, C; Yang, L; Ren, Y; Cui, W; Zhang, X; Zhang, P; Wang, J; Cui, Y.H and Bian, Xiu (2017): Cripto-1 acts as a functional marker of cancer stem-like cells and predicts prognosis of the patients in esophageal squamous cell carcinoma. Molecular Cancer, 16:81,1-12.

21. Mahmoudian, R. A; Abbaszadegan, M.R; Forghanifard, M.M; Moghbeli, M; Moghbeli, F; Chamani, J and Mehran Gholamin, M (2017): Biological and Clinicopathological Significance of Cripto-1 Expression in the Progression of Human ESCC. Reports of Biochemistry \& Molecular Biology Vol.5, No.2:1-8.

22. Mariotto, A., Yabroff, K., Shao, Y., Feuer, E. and Brown, M. (2011): Projections of the cost of cancer care in the United States: 2010-2020. J. Nati. Cancer Inst., 103(2):117-128.

23. Normanno, N., De Luca, A., Maiello, M., Bianco, C., Mancino, M., Strizzi, L., et al (2004). CRIPTO-1: a novel target for therapeutic intervention in human carcinoma. Int J Oncol, 25, 1013-1020.

24. Okamoto, A., Chikamatsu, K., Sakakura, K., Hatsushika, K., Takahashi, G., Masuyama, K. (2009): Expansion and characterization of cancer stem-like cells in squamous cell carcinoma of the head and neck. Oral Oncol., 45(7):633-639.

25. Oshimori, N., Oristian, D. and Fuchs, E. (2015): TGF-beta promotes heterogeneity and drug resistance in squamous cell carcinoma. Cell, 160(5):963-976.

26. Perez, A; Neskey, DM; Wen, J; Pereira, L; Reategui, EP; Goodwin, WJ; et al (2013): CD44 interacts with EGFR and promotes head and neck squamous cell carcinoma initiation and progression. Oral Oncol., 49(4):306-13.

27. Prince, M., Sivanandan, R., Kaczorowski, A., Wolf, G., Kaplan, M., Dalerba, P. et al (2007). Identification of a subpopulation of cells with cancer stem cell properties in head and neck squamous cell carcinoma. Proc.Natl.Acad.Sci. USA, 104: 973-978.

28. Satpute, P., Hazarey, V., Ahmed, R. and Yadav, L. (2013): Cancer stem cells in head and neck squamous cell carcinoma: A review. Asian Pac. J. Cancer Prev., 14 5579-5587.

29. Schier, AF (2003): Nodal signaling in vertebrate development. Annual review of cell and developmental biology; 19(1):589-621.

30. Strizzi, L; Bianco, C; Normanno, N; Seno, M; Wechselberger, C; Wallace-Jones, B et al (2004): Epithelial mesenchymal transition is a characteristic of hyperplasias and tumors in mammary gland from MMTV-Cripto-1 transgenic mice. Journal of cellular physiology; 201(2):266-76

31. Tirino, V., Desiderio, V., d'Aquino, R., De Francesco, F., Pirozzi, G., Graziano, A., et al. (2008): Detection and characterization of CD133+ cancer stem cells in human solid tumours. PLoS One, 3(10):e3469. 
32. Tsai, LL; Hu, FW; Lee, SS; Yu, CH; Yu, CC; Chang, YC (2014): Oct4 mediates tumor initiating properties in oral squamous cell carcinomas through the regula-tion of epithelial-mesenchymal transition. PLoS One, 9(1):e87207.

33. Tysnes, B., Satran, H., Mork, S., Margaryan, N., Eide, G., Petersen K., et al. (2013): Age-Dependent Association between Protein Expression of the Embryonic Stem Cell Marker Cripto-1 and Survival of Glioblastoma Patients. Transl. Oncol., 6:732-741.

34. Wei, B., Jin, W., Ruan, J., Xu, Z., Zhou, Y., Liang, J. et al. (2015): Cripto-1 expression and its prognostic value in human bladder cancer patients. Tumor Biology, 36(2):1105-1113.

35. Wei, B; Jin, W; Ruan, J; Xu, Z; Zhou, Y; Liang, J et al (2015). Cripto-1 expression and its prognostic value in human bladder cancer patients. Tumor Biology; 36(2):1105-13.

36. Wu, D., Shi, Z., Xu, H., Chen, R., Xue, S. and Sun, X. (2017): Knockdown of Cripto-1 inhibits the proliferation, migration, invasion, and angiogenesis in prostate carcinoma cells. J. Biosci., 42(3):405-416.

37. Wu, Z., Li, G., Wu, L., Weng, D., Li, X. and Yao, K. (2009): Cripto-1 overexpression is involved in the tumorigenesis of nasopharyngeal carcinoma. BMC cancer, 9(1):315.

38. Yanamoto S, Kawasaki G, Yamada S, Yoshitomi I, Kawano T, Yonezawa H, et al. (2011): Isolation and characterization of cancer stem-like side population cells in human oral cancer cells. Oral Oncol., 47(9):855-60.

39. Yanamoto, S., Kawasaki, G., Yamada, S., Yoshitomi, I., Kawano, T., Yonezawa, H., et al. (2011): Isolation and characterization of cancer stem-like side population cells in human oral cancer cells. Oral Oncol. 47(9):855860.

40. Ye, X., Tam, W., Shibue, T., Kaygusuz, Y., Reinhardt, F., Ng Eaton, E. and Weinberg, R. (2015): Distinct EMT programs control normal mammary stem cells and tumour-initiating cells. Nature, 525(7568):256-260.

41. Yoon H-J, Hong J-S, Shin W-J, Lee Y-J, Hong K-O, Lee J-I et al. (2011): The role of Cripto-1 in the tumorigenesis and progression of oral squamous cell carcinoma. Oral oncology.;47(11):1023-31.

42. Yoon, H., Hong, J., Shin, W., Lee, Y., Hong, K., Lee, J., et al., (2011): The role of Cripto-1 in the tumorigenesis and progression of oral squamous cell carcinoma. Oral Oncol., 47(11):1023-1031.

43. Yu, YH; Morales, J; Feng, L; Lee, JJ; El-Naggar, AK; Vigneswaran, N (2015): CD147 and Ki-67 overexpression confers poor prognosis in squamous cell carcinoma of oral tongue: a tissue microarray study. Oral Surg Oral Med Oral Pathol Oral Radiol., 119(5):553-65.

44. Zhang, J-G., Zhao, J. and Xin, Y. (2010): Significance and relationship between Cripto-1 and p-STAT3 expression in gastric cancer and precancerous lesions. World J. Gastroenterol., 16(5):571-577.

45. Zhang, Q., Shi, S., Yen, Y., Brown, J., Ta, J. and Le, A. (2010): A subpopulation of CD133(+) cancer stem-like cells characterized in human oral squamous cell carcinoma confer resistance to chemotherapy. Cancer Lett., 289:151-160.

46. Zini, A., Czerninski, R., Harold, D. and Cohen, S. (2010): Oral cancer over four decades: Epidemiology, trends, histology and survival by anatomical sites. J. Oral Pathol. Med., 39(4):299-305. 